\title{
Plasma Clozapine Levels and the Treatment of L-DOPA-Induced Psychosis in Parkinson's Disease
}

\section{A High Potency Effect of Clozapine}

Herbert Y. Meltzer, M.D., John Kennedy, M.D., Jin Dai, Mahmoud Parsa, M.D., and David Riley, M.D.

The purpose of this study was to determine the plasma level of clozapine and its metabolite, N-desmethylclozapine, in Parkinson's disease patients with L-DOPAinduced psychosis responsive to clozapine. The psychotic symptoms of the three patients studied responded to low doses of clozapine with plasma levels of clozapine between 4.5 and $16.1 \mathrm{ng} / \mathrm{ml}$ and $\mathrm{N}$-desmethylclozapine between 2.6 and $6.1 \mathrm{ng} / \mathrm{ml}$, much below the plasma clozapine levels usually found in clozapine-treated refractory schizophrenia or affective disorders (range 100 to
$687 \mathrm{ng} / \mathrm{ml}$ ). Possible mechanisms that may account for clozapine's antipsychotic action in dopaminomimeticinduced psychosis in Parkinson's disease, including serotonin $2 A\left(5-H T_{2 A}\right)$ and dopamine $D_{4}$ receptor blockade, at plasma levels that would be ineffective in refractory schizophrenia, are discussed. It is suggested that $5-\mathrm{HT}_{2 \mathrm{~A}}$ receptor blockade is the most likely basis for the effectiveness of clozapine in L-DOPA psychosis. [Neuropsychopharmacology 12:39-45, 1995]
KEY wORDs: Clozapine; L-DOPA; Parkinson's Disease; Psychosis

There is now extensive evidence that clozapine is an effective treatment of the delusions, visual hallucinations, and other psychotic symptoms such as thought disorder, produced by L-DOPA or bromocriptine in patients with Parkinson's disease (Scholz and Dichgans 1985; Freedman and Lannon 1989; Pfeiffer et al. 1990; Freedman 1991; Pinter and Helscher 1993). Typical neuroleptic drugs, even thioridazine, which produces the least pseudoparkinsonism of any antipsychotic drug,

From the Department of Psychiatry (HYM, JD, MP), Case Western Reserve University School of Medicine, Cleveland, Ohio; the Department of Psychiatry (JK), Vanderbilt University, Nashville, Tennessee; and the Department of Neurology (DR), Mt. Sinai Hospital, Cleveland, Ohio.

Address correspondence to: Herbert Y. Meltzer, M.D., Department of Psychiatry, University Hospitals of Cleveland, Hanna Pavillion, Room B-68, 11100 Euclid Avenue, Cleveland, OH 44106-5000.

Received May 14, 1994; revised July 14, 1994; accepted June 23, 1994. can also alleviate psychotic symptoms in these patients, but are rarely used because they cause an intolerable exacerbation of extrapyramidal symptoms (Scholz and Dichgans 1985; Freedman and Lannon 1989; Pfeiffer et al. 1990; Freedman 1991). Clozapine has been found to be extremely effective in reducing L-DOPA psychosis in Parkinson's disease in nearly all cases, at doses ranging from 6.25 to $150 \mathrm{mg} /$ day (median $62.5 \mathrm{mg} /$ day; Scholz and Dichgans 1985; Ostergaard and Dupont 1988; Freedman and Lannon 1989; Roberts et al. 1989; Kahn 1990; Pfeiffer et al. 1990; Freedman 1991; Pinter and Helscher 1993; Factor et al. 1994). The effect of clozapine is persistent (Factor et al 1994). This dose range is nearly an order of magnitude less than the 130 to 900 $\mathrm{mg} /$ day (mean $465 \mathrm{mg} /$ day) of clozapine required in the treatment of neuroleptic refractory schizophrenia (Meltzer 1992) and manic psychoses refractory to mood stabilizing drugs and neuroleptics (Calabrese and Meltzer 1991; Suppes et al. 1992). This difference in dosage required to treat psychosis in the common forms of se- 
vere mental illness and dopamine agonist-induced psychosis could be the result of pharmacokinetic or pharmacodynamic differences, or both.

Plasma levels of clozapine have been reported to predict clinical response in schizophrenia in two recent studies (Perry et al. 1991; Hasegawa et al. 1993). The mean plasma levels of clozapine in patients with schizophrenia who responded to clozapine were $404 \pm$ 199 (range 100 to 687) $\mathrm{ng} / \mathrm{ml}$ (Hasegawa et al. 1993). Mean N-desmethylclozapine plasma levels were $30.2 \%$ (Perry et al. 1991) and 75.0\% (Hasegawa et al. 1993), of plasma clozapine levels. Dose was positively correlated with plasma levels in one study (Hasegawa et al. 1993). The lowest effective doses in these two studies were $350 \mathrm{mg} /$ day (Perry et al. 1991) and $75 \mathrm{mg} /$ day (Hasegawa et al. 1993).

The purpose of this study was to determine the relationship, if any, between plasma clozapine levels and clinical response in patients with Parkinson's disease receiving clozapine for L-DOPA-induced psychosis. Plasma levels of the major metabolite of clozapine, $\mathrm{N}$-desmethylclozapine, were also studied.

\section{METHODS}

Two male patients, ages 71 and 77 , and one female, age 69 , with L-DOPA-induced psychoses and their guardians gave written informed consent to participate in this trial. The duration of Parkinson's disease and L-DOPA treatment were $6.1 \pm 0.3$ and $1.8 \pm 0.2$ years, respectively. The three patients had each developed a syndrome characterized by paranoid delusions and visual or auditory hallucinations that had been present for 4 , 18 , or 24 months, respectively. Two were moderately cognitively impaired and one severely cognitively impaired. The doses of carbidopa-L-DOPA (Sinemet ${ }^{*}$ ) at the time of initiating treatment with clozapine were $10 / 100$ t.i.d., in one patient and 12.5/50 t.i.d. mg/day in the other two patients. No other relevant psychotropic drugs were administered.

Clozapine treatment was initiated at a dose of 12.5 $(n=1)$ or $25(n=2) \mathrm{mg} /$ day and was titrated up to doses of $25(n=1)$ and $50(n=2) \mathrm{mg} / \mathrm{q}$. h.s. The dose of carbidopa/L-DOPA was increased 25 to $50 \%$ in all three patients 1 to 2 weeks after clozapine treatment was initiated and the psychosis decreased in order to further improve motor function. Compliance with taking clozapine was assured because caregivers gave clozapine to the three patients each night at bedtime.

Psychopathology, including mental status, was assessed by one of the authors (J.K., a psychiatrist), using the Schedule for Affective Disorders and Schizophrenia-Change rating scale (Endicott and Spitzer 1978) and the Mini-Mental Status examination (Folstein et al. 1975). Motor symptoms were assessed by a neurolo- gist (D.R.) using the Unified Parkinson's Disease Rating Scale.

Blood for plasma clozapine levels was obtained at 9:00 A.M. after 6 weeks or more of treatment when patients were receiving the doses described above. Each patient was studied at least twice. Plasma clozapine and $\mathrm{N}$-desmethylclozapine levels were determined by high pressure chromatography by a modification of the method of Lovdahl et al. (1991). All determinations were done in duplicate.

\section{RESULTS}

\section{Case Histories}

Case 1: G.R. is a 71-year-old male with a two-year history of Parkinson's disease. Twenty months after beginning treatment with carbidopa, L-DOPA, and bromocriptine, he developed visual and olfactory hallucinations that caused anxiety and agitation. Psychotic symptoms persisted even after stopping the bromocriptine. He had moderate-severe cognitive impairment (MiniMental State Exam [MMSE]=6). At the time of starting clozapine, he was receiving Sinemet ${ }^{\infty} 10 / 100$ t.i.d. Clozapine was started at $25 \mathrm{mg} /$ day, with improvement noted during the furst week. At a dose of $50 \mathrm{mg} /$ day, the visual and olfactory hallucinations as well as the associated agitation ceased. Motor symptoms also improved when the dose of Sinemet ${ }^{\star}$ was increased to $15 / 100 \mathrm{mg} /$ q.i.d., but cognitive function did not improve. No side effects of clozapine were noted. The patient's wife stated that clozapine prevented the need for nursing home placement.

Case 2: K.T. is a 77-year-old male with a 4-year history of Parkinson's disease. Treatment with intermittent carbidopa-L-DOPA provided some relief of motor symptoms but had to be stopped because of confusion and paranoia. Two trials of different neuroleptics at low doses were terminated because of severe rigidity. $\mathrm{He}$ was also unable to tolerate addition of trihexyphenidyl because of confusion. He was receiving 10/100 Sinemet ${ }^{(B)}$ q.i.d. but was severely bradykinetic and rigid. Prior to admission, he resided in a nursing home because of unmanageable aggressive behavior and had auditory hallucinations, severe depressive symptoms, and severe dementia (MMSE =2). With the first dose of clozapine (25 mg), aggressive behavior stopped. Within several days of reaching a dose of $50 \mathrm{mg} /$ day, dramatic improvement in delusions and hallucinations was noted. The dose of Sinemet ${ }^{\star}$ was increased to $15 / 100$ q.i.d. after 4 weeks without effect on mental status. Over a twomonth period, there was marked decrease in depressive symptoms, and Hamilton Depression Scale total ratings decreased from 33 to 14 . No change in MMSE occurred. Slight motor improvement was also noted. There were no side effects of note. 
Case 3: S.J. is a 69-year-old female with a 20-year history of Parkinson's disease. She developed psychotic symptoms when given either amantadine or Sinemet ${ }^{\star}$ $12.5 / 50$ t.i.d. At the time of admission, she had visual hallucinations, paranoid delusions about her husband, depression, and severe dementia (MMSE $=2$ ). Clozapine was begun at $12.5 \mathrm{mg} /$ day and increased to $25 \mathrm{mg} /$ day. Full remission of delusions was noted within the first week, and almost complete disappearance of the visual hallucinations was noted within three weeks. There were no side effects of clozapine noted. The dose of Sinemet ${ }^{\$}$ was increased to $25 / 100$ t.i.d. at 3 months and $37.5 / 150$ t.i.d. at 6 months. Improvement in depression was noted with the Hamilton Depression scale score decreasing from 25 at baseline to 12 at 6 months. Motor symptoms improved. There was no change in MMSE. The patient's husband noted marked improvement in quality-of-life (i.e., more rational communication and independent living), for both the patient and himself.

\section{Plasma Clozapine and N-Desmethylclozapine Levels}

Plasma clozapine levels in patients 1 to 3 were $16.1,6.8$, and $4.5 \mathrm{ng} / \mathrm{ml}$, at doses of 50,50 , and $25 \mathrm{mg} /$ day, respectively. Plasma N-desmethylclozapine levels were 5.1, 4.9 , and $2.6 \mathrm{ng} / \mathrm{ml}$, respectively.

\section{DISCUSSION}

The major finding of this study is that clozapine was very rapidly effective in reducing paranoid delusions and visual or auditory hallucinations in three L-DOPAtreated patients with Parkinson's disease at doses of clozapine that produced plasma levels of clozapine and $\mathrm{N}$-desmethylclozapine of less than $25 \mathrm{ng} / \mathrm{ml}$. These levels are 40- to 50-fold lower than those usually required to treat refractory schizophrenia or mania (e.g., 300 to $500 \mathrm{ng} / \mathrm{ml}$ ). They are also significantly lower than those plasma levels generally necessary to treat nontreatmentresistant schizophrenic patients ( 150 to $200 \mathrm{ng} / \mathrm{ml}$; Haring et al. 1990; Meltzer et al. unpublished data). It is extremely unlikely that noncompliance was the cause of low clozapine levels in these patients because of caregiver assistance. Thus, it seems likely that the rapid and robust response of psychotic symptoms resulting from L-DOPA in patients with Parkinson's disease occurred at plasma clozapine levels that are far below those usually needed to ameliorate positive psychotic symptoms (i.e., delusions and hallucinations) in refractory schizophrenia or mania. This has been found to be $\geqslant 350 \mathrm{ng} / \mathrm{ml}$ in most patients but can be as low as $100 \mathrm{ng} / \mathrm{ml}$ (Perry et al. 1991; Hasegawa et al. 1993). It is noteworthy that the response to clozapine in the cases reported here as well as those in previous reports of clozapine treatment of Parkinson's disease with L-DOPAinduced psychosis (Freedman and Lannon, 1989; Freedman 1991) is so much more rapid than that generally observed in schizophrenic patients (Kane et al. 1988).

These findings raise a number of important questions. The first issue is how closely these plasma levels reflect brain levels. In the rodent, brain levels of clozapine have been reported to be fivefold higher than plasma levels in one study (Gauch and Michaelis 1970). In a second study, clozapine levels were 7.2-fold higher in brain than serum at brain clozapine levels lower than or equal to $5 \mu \mathrm{g} / \mathrm{g}$, whereas for all brain clozapine levels, the brain clozapine levels were 24.3 times higher than serum levels (Baldessarini et al. 1993). The higher brain clozapine levels were attributed to effect of free plasma clozapine, lipophilicity and penetration of the blood brain barrier, binding to cellular elements in brain, and local brain metabolism (Baldessarini et al. 1993). It is unknown if similar differences between brain and serum clozapine levels exist for humans. Presumably, there is some degree of concentration of clozapine in human brain as well. However, unless this effect differs in Parkinson's disease patients and patients with schizophrenia, it is still the case that the plasma and presumably brain clozapine levels needed for an antipsychotic effect are much lower in Parkinson's disease.

The rapid response of positive symptoms to clozapine in L-DOPA-induced psychosis suggests a direct antagonist effect on a receptor for which clozapine has a relatively high affinity and which might be related to psychosis (e.g., the $\mathrm{D}_{1}, \mathrm{D}_{2}$, or $\mathrm{D}_{4} \mathrm{DA}$ receptor), a serotonin (5-HT) receptor (e.g., the 5- $\mathrm{HT}_{2 \mathrm{~A}}, 5-\mathrm{HT}_{2} \mathrm{C}$, $5-\mathrm{HT}_{3}, 5-\mathrm{HT}_{6}$, or $5-\mathrm{HT}_{7}$ receptors); or some presynaptic effect (e.g., decreased release of DA), which might lead to decreased postsynaptic dopaminergic activity. Antipsychotic effects mediated by actions at the alpha ${ }_{1}$ adrenergic (Baldessarini et al. 1992) or muscarinic receptors (Bolden et al. 1991, 1992) are also possible. More slowly developing adaptive effects on the density of receptors or second messenger systems cannot be excluded because a single dose of clozapine can downregulate $5-\mathrm{HT}_{2}$ receptors (Matsubara and Meltzer 1989). Chronic clozapine treatment has usually been reported not to alter the number of $D_{1}$ or $D_{2}$ receptors in mesostriatal DA regions (Rupniak et al. 1984; Ashby et al. 1989b), but a recent autoradiographic study reported 21 days treatment with clozapine downregulated $\mathrm{DA} \mathrm{D}_{2}$ receptor density in several mesolimbocortical areas (Giardino et al. 1991).

Recently, remoxipride, a relatively specific $D_{2}$ receptor antagonist with some sigma receptor blocking properties (Köhler et al. 1990) was also reported to reduce visual hallucinations and psychotic thinking in four of five Parkinson's disease patients receiving L-DOPA with or without bromocriptine or selegiline 
(Eriksson and Olsson 1993). One patient whose psychosis had responded to clozapine did not respond to remoxipride. The dose of remoxipride that was effective was $150 \mathrm{mg} /$ day $(n=3)$ and $50 \mathrm{mg} /$ day $(n=1)$. The usual clinical dose of remoxipride in schizophrenia is 300 to $400 \mathrm{mg} /$ day (Lewander et al. 1980). Thus, the clinically effective dose of remoxipride in L-DOPAinduced psychosis is nearly comparable to that in schizophrenia, especially if one adjusts for the likelihood of lower dose requirement in the elderly. The effect of remoxipride in L-DOPA psychosis is most likely a result of its potent $D_{2}$ receptor blockade, although sigma antagonism, a property it shares with clozapine, cannot be ruled out. Remoxipride has no affinity for the $D_{1}$ receptor, which has been suggested to be the basis for the ability of clozapine to block L-DOPA-induced psychosis (Pinter and Helscher 1993). Like clozapine, remoxipride did not worsen parkinsonian symptoms in these patients, suggesting that it did not produce effective blockade of $D_{2}$ receptors in the striatum or inactivate nigrostriatal dopaminergic neurons. Clozapine has been shown to be a relatively weak antagonist at human striatal $D_{2}$ receptors, at least in the striatum (Fardé et al. 1992). However, it has been shown that clozapine blocks $D_{2}$ receptors to a greater extent in the rat limbic system than the striatum (Stockmeier et al. 1993). It is possible that clozapine and remoxipride could be much more effective in blocking mesolimbic $D_{2}$ receptors than striatal $D_{2}$ receptors.

The 5- $\mathrm{HT}_{3}$ receptor antagonist, ondansetron, has also recently been reported to completely block L-DOPAinduced visual hallucinations in three patients and partially in four patients with Parkinson's disease (Zoldan et al. 1994). This effect was rapidly reversible with temporary discontinuation of ondansetron. The basis for this effect was suggested to be blockade of the effect of 5-HT released from serotonergic nerve terminals by DA formed in these terminals from L-DOPA. However, visual hallucinations are most likely the result of $5-\mathrm{HT}_{2 \mathrm{~A}}$ or $5-\mathrm{HT}_{2} \mathrm{C}$ receptor stimulation (Sadzot et al. 1989). Antagonism of $5-\mathrm{HT}_{3}$ receptors might be expected to decrease the release of DA by antagonizing $5-\mathrm{HT}_{3}$ heteroreceptors that enhance the release of DA (Blandina et al. 1988). Ondansetron also decreases the effect of intraaccumbens amphetamine on DA-mediated behaviors (Costall et al. 1987) and amphetamineinduced hunger in man (Silverstone et al. 1992). Thus, ondansetron might be effective in this syndrome by decreasing the release of DA. Clozapine is an effective $5-\mathrm{HT}_{3}$ antagonist in vivo, but its potency is relatively weak (Ashby et al. 1989a). Thus, it seems unlikely that $5-\mathrm{HT}_{3}$ antagonism could explain the action of clozapine at the low concentrations observed in this study.

Clozapine has been reported to block $\mathrm{D}_{4} \mathrm{DA}$ receptors at concentrations 15.3 times lower than that required to block $D_{2}$ receptors (Van Tol et al. 1991). It is possible that stimulation of supersensitive $D_{4}$ receptors by DA derived from L-DOPA may be the basis for the psychotic symptoms in Parkinson's disease. If so, antagonists selective for $D_{4}$ as compared to $D_{2}$ receptors might be effective in patients with Parkinson's disease who develop L-DOPA-induced psychotic symptoms. It may also be possible that supersensitive DA receptors of various types develop in the limbic as well as the striatal system in some patients with Parkinson's disease. The affinity of clozapine for the supersensitive $\mathrm{D}_{4}$ receptors in limbic regions might be sufficiently augmented so that they are capable of being occupied by very low concentrations of clozapine that are ineffective in schizophrenia or mania. It has previously been demonstrated that atypical antipsychotics, including clozapine, sulpiride, and thioridazine, have increased potency at supersensitive postsynaptic DA receptors (see Meltzer 1991 for review).

It is possible that the L-DOPA-induced psychosis in Parkinson's disease is related to an excess of $D_{2}$ receptor-mediated dopaminergic neurotransmission because it also occurs with the direct-acting DA agonist bromocriptine, which is a mixed $D_{1} / D_{2}$ agonist and is effectively antagonized by the selective $D_{2}$ antagonist remoxipride. Because clozapine produced only weak blockade of $D A D_{2}$ receptors, the possibility must be considered that some nondopaminergic mechanism(s) are involved in the antipsychotic action of clozapine in both L-DOPA-induced psychosis and schizophrenia, for example, antagonist effects on $5-\mathrm{HT}_{2 \mathrm{~A}}, 5-\mathrm{HT}_{2 \mathrm{C}}$, $5-\mathrm{HT}_{3}, 5-\mathrm{HT}_{6}, 5-\mathrm{HT}_{7}, \alpha_{2}$-adrenergic, muscarinic, or sigma receptors, or enhancement of glutamatergic function (Meltzer 1991; Roth et al 1994), and that these effects may occur at much lower concentrations in L-DOPA-induced psychosis than in schizophrenia or mania. The recent demonstration that very low doses of risperidone also block L-DOPA-induced visual hallucinations in Parkinson's disease suggests that both clozapine and risperidone are primarily acting via $5-\mathrm{HT}_{2 \mathrm{~A}}$ receptor blockade because risperidone is a potent $5-\mathrm{HT}_{2 \mathrm{~A}}$ antagonist with relatively weak $\mathrm{D}_{2}, \mathrm{D}_{4}$, and $5-\mathrm{HT}_{2} \mathrm{C}$ affinities (Roth et al. 1992; Schotte et al. 1993; Megens et al. 1994). Schremmer et al. (1990) demonstrated that ritanserin, a selective $5-\mathrm{HT}_{2 \mathrm{~A} / 2 \mathrm{C}}$ antagonist, and cyproheptadine, a nonselective 5-HT antagonist, were, like clozapine, able to block the supersensitive component of apomorphine-induced locomotor activity in 6-OHDA-pretreated rats. Because haloperidol, which lacks 5-HT antagonist properties, was relatively ineffective in this model, it was suggested that $5-\mathrm{HT}_{2 \mathrm{~A} / 2 \mathrm{C}}$ receptor stimulation might enhance dopaminergic supersensitivity.

Nausieda et al. (1983) previously suggested that L-DOPA-induced psychosis may occur via a serotonergic mechanism. They proposed that L-DOPA may induce a decrease in brain 5-HT concentration (by com- 
petition for L-tryptophan transport and displacement of 5-HT from nerve terminals following uptake of L-DOPA into 5-HT neurons) or an increase in 5-HT receptor sensitivity, or both. We suggest this might be the $5-\mathrm{HT}_{2 \mathrm{~A}}$ receptor. Blockade of $5-\mathrm{HT}_{2 \mathrm{~A}}$ receptors might lead to a suppression and normalization of mesolimbic and mesocortical dopaminergic activity (Ugedo et al. 1989; Sorensen et al. 1993). Blockade of 5-HT $2 \mathrm{~A}$ receptors may be the basis of the action of clozapine in schizophrenia, mania, and psychotic depression as well. The difference in potency of both clozapine and risperidone in Parkinson's disease and these other psychoses may be a result of the need for only minimal interference with 5- $\mathrm{HT}_{2 \mathrm{~A}}$ receptor stimulation in Parkinson's disease.

Nausieda and colleagues also suggest the importance of enhanced and dysregulated activity of the hypothalamo-pituitary-adrenal axis in L-DOPA psychosis, especially if accompanied by sleep disruption (Nausieda et al. 1982a, c). They proposed that glucocorticoids may enhance behavioral supersensitivity to 5-HT (Nausieda et al. 1982b). We have reported that clozapine decreases plasma glucocorticoid levels (Meltzer 1989). It is possible that this may be a factor in clozapineinduced suppression of L-DOPA- or bromocriptineinduced psychosis.

Other possible sensitive antipsychotic actions that could block L-DOPA psychosis of clozapine include modulation of glutamatergic function. Clozapine has recently been reported to block the locomotor activity and stereotypy produced by the NMDA receptor antagonist MK-801 in the rat at doses 11.2-fold lower than those required to block $D_{2}$-mediated behavior exhibited in the climbing mouse assay (Wettlaufer et al. 1993). Thus, clozapine appears to be much more potent against an NMDA-receptor mediated model of psychosis than a dopaminomimetic mechanism.

In conclusion, it has been found that clozapine is an effective treatment of L-DOPA-induced psychosis in Parkinson's disease at doses that produce plasma clozapine or N-desmethylclozapine levels $\leqslant 25 \mathrm{ng} / \mathrm{ml}$. The basis for its antipsychotic action may be $5-\mathrm{HT}_{2 \mathrm{~A}}$ receptor blockade, although an inhibitory effect at $\mathrm{D}_{4}$ receptors, decrease in glucocorticoid output, and enhancement of glutamatergic function are also possibilities. Further study of the L-DOPA or bromocriptine psychoses in Parkinson's disease might provide new insights into the role of DA and other neurotransmitters in several types of psychosis as well as the basis of the antipsychotic action of clozapine.

\section{ACKNOWLEDGMENTS}

The research reported was supported in part by USPHS MH 41684, GCRC MO1RR00080, and the National Alliance for Research on Schizophrenia and Depression (NARSAD) as well as grants from the Elisabeth Severance Prentiss and John Pascal Sawyer Foundations and Stanley Foundation. H.Y.M. is the recipient of a USPHS Research Career Scientist Award $\mathrm{MH} 47808$. The secretarial assistance of Ms. Lee Mason is greatly appreciated.

\section{REFERENCES}

Ashby CR Jr, Edwards E, Harkins K, Wang RY (1989a): Characterization of 5-hydroxy-tryptamine 3 receptors in the medial prefrontal cortex: A microiontophoretic study. Eur J Pharmacol 173:193-196

Ashby CR, Hitzemann R, Rubinstein JE, Wang RY (1989b): One year treatment with haloperidol or clozapine fails to alter neostriatal $D_{1}$ - and $D_{2}$-dopamine receptor sensitivity in the rat. Brain Res 493:194-197

Baldessarini RJ, Huston-Lyons D, Campbell A, Marsh E, Cohen BM (1992): Do central antiadrenergic actions contribute to the atypical properties of clozapine? Brit J Psychiatr 160:12-16

Baldessarini RJ, Centorrino F, Flood JG, Volpicelli SA, HustonLyons D, Cohen BM (1993): Tissue concentrations of clozapine and its metabolites in the rat. Neuropsychopharmacology 9:117-124

Blandina P, Goldfarb J, Green JP (1988): Activation of a 5- $\mathrm{HT}_{2}$ receptor releases dopamine from rat striatal slices. Eur J Pharmacol 155:349-350

Bolden C, Cusack B, Richelson E (1991): Clozapine is a potent and selective muscarinic antagonist at the five cloned human muscarinic cholinergic receptors expressed in CHO-K1 cells. Eur J Pharmacol 192:205-206

Bolden C, Cusack B, Richelson E (1992): Antagonism by antimuscarinic and neuroleptic compounds at the five cloned human muscarinic cholinergic receptors expressed in Chinese hamster ovary cells. J Pharmacol Exp Ther 260:576-580

Calabrese JR, Meltzer HY (1991): Clozapine prophylaxis in rapid cycling bipolar disorder. J Clin Psychopharmacol 11:396-297

Costall B, Domency AM, Naylor RJ, Tyers MD (1987): Effect of the $5-\mathrm{HT}_{3}$ receptor antagonist, GR $38032 \mathrm{~F}$, on raised dopaminergic activity in the mesolimbic system of the rat and marmoset brain. Br J Pharmac 92:881-894

Endicott J, Spitzer RL (1978): A diagnostic interview: The schedule for affective disorders and schizophrenia. Arch Gen Psychiatry 35:837-844

Eriksson L, Olsson JO (1993): Remoxipride in the treatment of dopaminomimetic-therapy induced psychosis in Parkinson's disease: Five case histories. Eur Neuropsychopharmacol 3:381

Factor SA, Brown D, Molho ES, Podskalny GD (1994): Clozapine: A 2-year open trial in Parkinson's disease patients with psychosis. Neurology 44:544-546

Fardé L, Nordström AL, Wiesel FA, Pauli S, Halldin C, Sedvall $G$ (1992): Positron emission tomographic analysis of central $D_{1}$ and $D_{2}$ dopamine receptor occupancy in patients treated with classical neuroleptics and clozapine. Arch Gen Psychiatry 49:538-544

Folstein MF, Folstein SE, McHugh PR (1975): Mini-Mental State: A Practical Method for Grading the Cognitive State 
of Patients for the Clinician. J of Psycholinguistic Research 12:189-198

Freedman JH (1991): The management of the levodopa psychoses. Clin Neuropharmacol 14:283-295

Freedman JH, Lannon MC (1989): Clozapine in the treatment of psychosis in Parkinson's disease. Neurology 39: 1219-1221

Gauch R, Michaelis W (1970): The metabolism of 8-chloro11-(4-methyl-1-piperazinyl)-5H-dibenzo[b,e][1,4]diazepine (clozapine) in mice, dogs and human subjects. II Farmaco 26:667-681

Giardino L, Calzà L, Piazza PV, Amato G (1991): Multiple neurochemical action of clozapine: a quantitative autoradiographic study of DA2, opiate and benzodiazepine receptors in the rat brain after long-term treatment. J Neural Transm [Gen Sect] 83:189-203

Haring C, Fleishhacker W, Schett P, Humpel C, Barnas C, Saria A (1990): Influence of patient-related variables on clozapine plasma levels. Am J Psychiatry 147:1471-1475

Hasegawa M, Gutierrez-Esteinou R, Way L, Meltzer HY (1993): Relationship between clinical efficacy and clozapine plasma levels in schizophrenia: Effect of smoking. J Clin Psychopharmacol 13:383-390

Kahn NA (1990): Clozapine for psychosis in Parkinson's patients. Clin Adv Treat Psychiatr Disord 4:12-16

Köhler C, Hall H, Magnusson O, Lewander T, Gustafsson $\mathrm{K}$ (1990): Biochemical pharmacology of the atypical neuroleptic remoxipride. Acta Psychiatr Scand 82(Suppl 358):27-36

Lewander T, Westerbergh S-E, Morrison D (1980): Clinical of remoxipride-a combined analysis of a comparative double-blind, multicentre trial programme. Acta Psychiatr Scand 82(Suppl 358):92-98

Lovdahl MJ, Perry PJ, Miller DD (1991): The assay of clozapine and $N$-desmethyl-clozapine in human plasma by high-performance liquid chromatography. Ther Drug Monit 13:69-72

Matsubara S, Meltzer HY (1989): Effect of typical and atypical antipsychotic drugs on $5-\mathrm{HT}_{2}$ receptor density in rat cerebral cortex. Life Sci 45:1397-1406

Meco G, Alessandria A, Bonifati V, Giustini P (1994): Risperidone for hallucinations in levodapa-treated Parkinson's disease patients. Lancet 343:1370-1371

Megens AAHP, Awouters FHL, Schotte A, Meert TF, Dugovic C, Niemegeers CJE, Leysen JE (1994): Survey on the pharmacodynamics of the new antipsychotic risperidone. Psychopharmacology 114:9-23

Meltzer HY (1989): Clinical studies on the mechanism of action of clozapine: The dopamine-serotonin hypothesis of schizophrenia. Psychopharmacology 99:S18-S2

Meltzer HY (1991): The mechanism of action of novel antipsychotic drugs. Schizophr Bull 17:263-287

Meltzer HY (1992): Treatment of the neuroleptic non-responsive schizophrenic patient. Schizophrenia Bull 18:515-542

Nausieda PA, Baum RM, Weiner WJ (1982a): Cortisol disruption as a side effect of chronic levodopa therapy (abstr). Nedurology 32:4, part II, A180

Nausieda PA, Carvey PM, Weiner WJ (1982b): Modification of central serotonergic and dopaminergic behaviors in the course of chronic corticosteroid administration. Eur J Pharmacol 78:335-343

Nausieda PA, Weiner WJ, Kaplan LR, Weber S, Klawans H (1982c): Sleep disruption in the course of chronic levodopa therapy: An early feature of the levodopa psychosis. Clin Neuropharmacol 5:183-194

Nausieda PA, Tanner CM, Klawans HL (1983): Serotonergically active agents in levodopa-induced psychiatric toxicity reactions. In Fahn S, Calne DB, Shoulson I (eds), Advances in Neurology, Vol. 37: Experimental Therapeutics of Movement Disorders, New York, Raven Press, pp 23-32

Ostergaard K, Dupont E (1988): Clozapine treatment of druginduced psychotic symptoms in the late stages of Parkinson's disease. Acta Neurol Scand 78:349-350

Perry PJ, Miller DD, Arndt SV, Cadoret RJ (1991): Clozapine and norclozapine plasma concentrations and clinical response of treatment-refractory schizophrenic patients. Am J Psychiatry 148:231-235

Pfeiffer RF, Kang J, Graber B, Hofman R, Wilson J (1990): Clozapine for psychosis in Parkinson's disease. Movement Dis 5:239-242

Pinter MM, Helscher RJ (1993): Therapeutic effects of clozapine in psychotic decompensation in idiopathic Parkinson's disease. J Neural Transm (P-D Sec) 5:135-146

Roberts HE, Dean RC, Studemire A (1989): Clozapine treatment of psychosis in Parkinson's disease. J Neuropsychiatr Clin Neurosci 1:190-192

Roth BL, Ciaranello RD, Meltzer HY (1992): Bindings of typical and atypical antipsychotic agents to transiently expressed 5-HT $1 \mathrm{C}$ receptors. J Pharmacol Exp Ther 260: 1361-1365

Roth BL, Craigo SC, Choudhary MS, Uler A, Monsma FJ, Shen Y, Meltzer HY, Sibley DR (1994): Binding of typical and atypical antipsychotic agents to 5-hydroxytryptamine $_{6}\left(5-\mathrm{HT}_{6}\right)$ and 5-hydroxytryptamine $\left(5-\mathrm{HT}_{7}\right)$ receptors. J Pharmacol Exp Ther 268:1406-1410

Rupniak NMJ, Kilpatrick G, Hall MD, Jenner P, Marsden CD (1984): Differential alterations in striatal dopamine receptor sensitivity induced by repeated administration of clinically equivalent doses of haloperidol, sulpiride or clozapine in rats. Psychopharmacology 84:512-519

Sabzot B, Baraban JM, Glennon RA, Lyon RA, Leonhardt S, Jan C-R, Titeler M (1989): Hallucinogenic drug interactions at human brain $5-\mathrm{HT}_{2}$ receptors: Implications for treating LSD-induced hallucinogenesis. Psychopharmacology 98:495-499

Scholz E, Dichgans J (1985): Treatment of drug-induced endogenous psychosis in parkinsonism with clozapine and fluperlapine. Eur Arch Psychiatr Neurol Sci 235:60-64

Schotte A, Janssen PFM, Megens AAHP, Leysen JE (1993): Occupancy of central neurotransmitter receptors by risperidone, clozapine, and haloperidol, measured ex vivo by quantitative autoradiography. Brain Res 631: 191-202

Schremmer C, Morgenstern R, Fink H, Oh T (1990): Atypical neuroleptics suppress dopaminergic behavioral supersensitivity. Psychopharmacology 100:399-403

Silverstone PH, Johnson B, Cowen PJ (1991): Does ondanse- 
tron attenuate amphetamine-induced behaviour in human volunteers? Psychopharmacology 107:140-141

Sorensen SM, Kehne JA, Fadayel GM (1993): Characterization of the 5- $\mathrm{HT}_{2}$ receptor antagonist MDL 100,907 as a putative atypical antipsychotic: Behavioral, electrophysiological and neurochemical studies. J Pharmacol Exp Ther 266:684-691

Stockmeier CA, DiCarlo JJ, Zhang Y, Thompson P And Meltzer HY (1993): Characterization of typical and atypical antipsychotic drugs based on in vivo occupancy of serotonin 2 and dopamine 2 receptors. J Pharmacol Exp Ther 266:1374-1384

Suppes T, McElroy SL, Gilbert J, Dessain EC, Cole JO (1992): Clozapine in treatment of dysphoric mania. Biol Psychiatr 32:270-280
Ugedo L, Grenhoff J, Svensson TH (1989): Ritanserin, a 5- $\mathrm{HT}_{2}$ receptor antagonist, activates mid-brain DA neurons by blocking serotonergic inhibition. Psychopharmacology 98:45-50

Van Tol HHM, Bunzow JR, Guan H-C, Sunahara RD, Seeman P, Niznik HB, Civelli O (1991): Cloning of the gene for a human $\mathrm{D}_{4}$ receptor with higher affinity for dopamine than $D_{1}$. Nature 350:614-619

Wettlaufer TA, Camaelio F, Fishkin RJ, Kerman LL, Woods AT, Corbet R (1993): The atypical antipsychotic agent clozapine. Neurosci Abs 19:1391

Zoldan J, Frieberg G, Goldberg-Stern H, Melamed E (1993): Ondansetron for hallucinosis in advanced Parkinson's disease. Lancet 341:562-563 